\title{
STUDY OF THE WORKABILITY AND MECHANICAL PROPERTIES OF CONCRETE WITH ADDED GROUND CORNCOBS
}

\section{ŠTUDIJA IZVEDLJIVOSTI IN MEHANSKIH LASTNOSTI BETONA Z DODATKOM ZDROBLJENIH KORUZNIH STORŽEV}

\author{
Wojciech Życiński, Marcin Małek*, Mateusz Jackowski, Waldemar Lasica, \\ Mariusz Owczarek \\ Military University of Technology, Faculty of Civil Engineering and Geodesy, 2 gen. Sylwestra Kaliskiego, 00-908 Warsaw, Poland
}

Prejem rokopisa - received: 2019-07-27; sprejem za objavo - accepted for publication: 2020-03-23

\author{
doi:10.17222/mit.2019.182
}

\begin{abstract}
This work reports on how Portland cement was modified by adding ground corncobs to its matrix. The main purpose of this study was to observe direct influence of the addition on the concrete mechanical properties. The recipe for the modified concrete included three amounts of ground corncobs: $3 w / \%, 5 w / \%, 10 w / \%$. Fresh concrete mix was tested for air content and $\mathrm{pH}$ value. Samples of concrete were characterized with the compressive strength, tensile splitting strength and bending strength after $28 \mathrm{~d}$ of curing. The porosity and thermal properties of the concrete were also measured. Summarized results were compared with the reference samples. Physical characteristics and thermal parameters of the concrete were determined. This study proved that ground corncobs decrease the final mechanical properties of the studied concrete.

Keywords: concrete, corncob, mechanical strength, modification

$\mathrm{V}$ prispevku avtorji predstavljajo rezultate modifikacije betona na osnovi portlandskega cementa $\mathrm{z}$ dodatkom zdrobljenih koruznih storžev v matrico. Glavni namen pričujoče študije je bil ugotoviti neposreden vpliv izbranega dodatka na mehanske lastnosti betona. Pripravljeni beton je vseboval tri različne vsebnosti dodatka zdrobljenih koruznih storžev in sicer: (3, 5 in 10) w/\%. Svežim mešanicam betona so določili vsebnost zraka in njihovo bazičnost oz. alkalnost (pH). Po 28-dneh sušenja izdelanih vzorcev betona so določili njihovo tlačno, natezno-cepilno in upogibno trdnost. Prav tako so izmerili njihovo poroznost in termične lastnosti. Rezultate so primerjali z referenčnim vzorcem betona. S študijo so dokazali, da dodatek zdrobljenih storžev v matrico betona poslabša končne mehanske lastnosti preiskovanega betona.

Ključne besede: beton, koruzni storži, mehanska trdnost, modifikacija
\end{abstract}

\section{INTRODUCTION}

Millions of tons of waste are produced worldwide each year, and most of them are not recyclable. In addition, waste recycling consumes energy and causes pollution. Waste collection and disposal are harmful to the environment. The use of waste in the production of concrete is an appropriate method to achieve two goals: waste elimination and change of the concrete properties.

Around $20-30 \%$ of agricultural production becomes waste. ${ }^{1-4}$ Using the waste from agricultural products has attracted the attention of scientists who wish to bring it back into the economic cycle. The most popular agricultural waste includes rice husk and corncob. ${ }^{5-8}$

An addition of corncob as a substitute for a light aggregate significantly changes the properties of a fresh concrete mix, such as the flow or porosity, and also affects the strength properties of concrete by lowering them in part. Some researchers indicate that this additive can improve the insulation properties of concrete. ${ }^{9-11}$

*Corresponding author's e-mail: marcin.malek@wat.edu.pl (Małek Marcin)
The main results obtained are presented and discussed, showing that the proposed corncob concrete may have the material properties required for mortar or insulation concrete. ${ }^{12-15}$ If the amount of the addition is large, not just a small fraction like in most research cases, the additive causes an increase in the insulation; such concrete could be used, e.g., in cold rooms because its density decreases while the thermal conductivity and porosity increase. ${ }^{16-18}$

\section{EXPERIMENTAL PART}

The subject of the research was the addition of ground corncobs (Figure 1), the waste from agricultural products, to the concrete matrix. The addition of this organic additive was designed for investigating the effect of ground corncobs on the final mechanical and physico-chemical properties of concrete.

Four mixtures were made, all based on CEM I. The first was the reference concrete mix, not including any addition of corncobs. The rest of them had $3 w / \%, 5 w / \%$ and $10 \mathrm{w} / \%$ additions. From the mixtures, one sample was used, at a time, for the tensile and bending tests and 

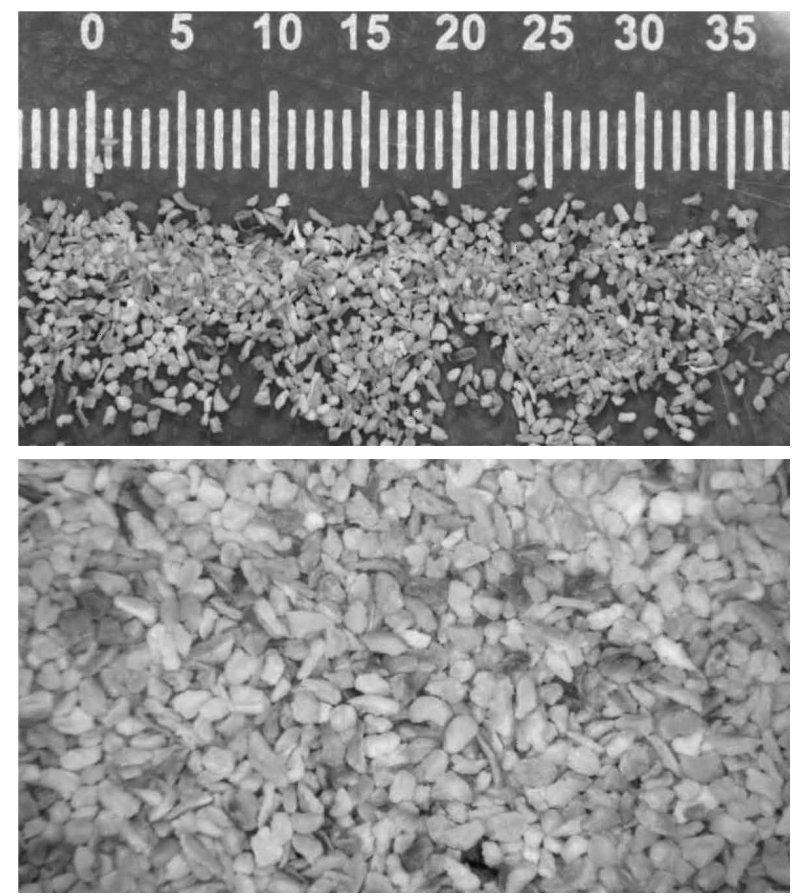

Figure 1: Ground corncobs

two for the compression test. All samples were cured in water for $28 \mathrm{~d}$.

A deflocculant based on polycarboxylates reducing the amount of water and improving the workability of the concrete mix was used for the tests. Its amount was $1 \%$ in the first three mixtures and $1.5 \%$ in the fourth one. Due to the very difficult workability, it was necessary to add more liquefier and it was decided to increase its quantity by $50 \%$ in comparison to the other samples. The additive had no direct effect on the increase or decrease in the strength of the samples. All the research parameters were in line with European Standard EN 206-1:2011.

\section{RESULTS AND DISCUSSION}

First, the fresh concrete mixture was tested. A slump test was done. In the reference mixture, a decrease by 20

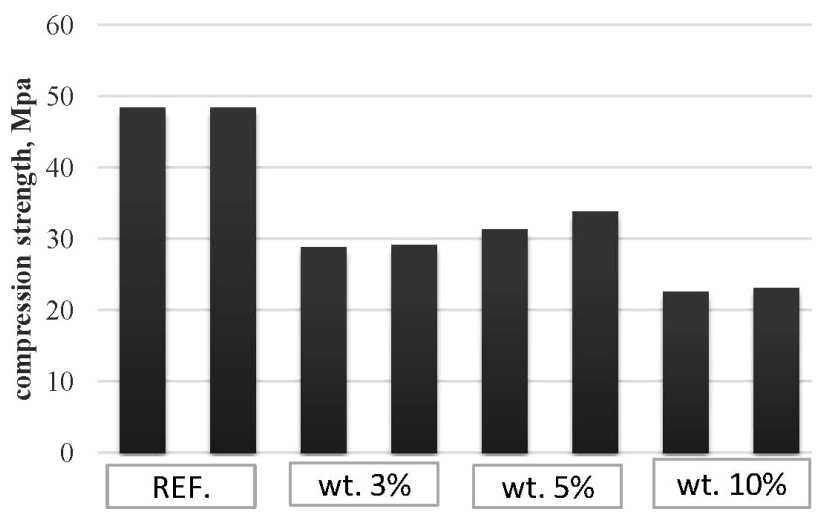

Figure 2: Compressive-strength distribution, MPa $\mathrm{mm}$ was achieved, which classifies it as the S1 class. In the cases of adding corncob to the concrete, the mixtures did not exhibit any decrease. The air content in the mixtures was also checked. The reference mixture exhibited a value of $2 w / \%$. Moreover, with the increasing amount of corncob, the mixture had (3, 4 and 4.6) w/\% of air (Table 1).

Table 1: Density and porosity of the mixtures

\begin{tabular}{|c|c|c|c|}
\hline & $\begin{array}{c}\text { Bulk density } \\
\rho_{0} /\left(\mathrm{kg} / \mathrm{dm}^{3}\right)\end{array}$ & $\begin{array}{c}\text { Tightness } \\
\text { ratios } / \%\end{array}$ & $\begin{array}{c}\text { Porosity ratio } \\
p / \%\end{array}$ \\
\hline Ref. mix & 2.59 & 92.4 & 7.6 \\
\hline Mix 1 $(3 w / \%)$ & 2.52 & 89.9 & 10.1 \\
\hline Mix 2 $(5 w / \%)$ & 2.50 & 89.4 & 10.6 \\
\hline Mix 3 $(10 w / \%)$ & 2.40 & 85.7 & 14.3 \\
\hline
\end{tabular}

The obtained results showed a decrease in the compression strength to $22.5 \mathrm{MPa}$, noted for $10 \mathrm{w} / \%$ of ground corncobs after $28 \mathrm{~d}$ of curing (Figure 2). The lowest decrease of the compression strength was observed for $5 \mathrm{w} / \%$ corncobs and its maximum was 33.8 MPa on the same day of measuring. All the samples exhibit a decrease due to the addition. The consequences of this process included a formation of large air voids and decomposition of the concrete.

The $\mathrm{pH}$ was checked and a slight decrease from 13.0 to $12.7 \%$ was found (for $3 \%$ and $5 \%$ of corncob) and $12.6 \%$ for the $10 \%$ of corn cob (Table 2).

Table 2: PH values of the mixtures

\begin{tabular}{|c|c|c|c|c|}
\hline & $\begin{array}{c}\text { Ref. } \\
\text { mix }\end{array}$ & $\begin{array}{c}\text { Mix 1 } \\
(3 w / \%)\end{array}$ & $\begin{array}{c}\text { Mix 2 } \\
(5 w / \%)\end{array}$ & $\begin{array}{c}\text { Mix 3 } \\
(10 w / \%)\end{array}$ \\
\hline $\mathrm{pH}$ & 12.98 & 12.70 & 12.77 & 12.63 \\
\hline
\end{tabular}

Figure 3 shows the results of the bending-strength distribution of the prepared samples. The largest strength was observed for the lowest addition, the amount of $3 w / \%$. Other samples exhibited very similar characteristics of the bending strength. Figure 4 shows the Brazilian tensile strength (BTS), but under different conditions as the splitting strength shows the same results as the

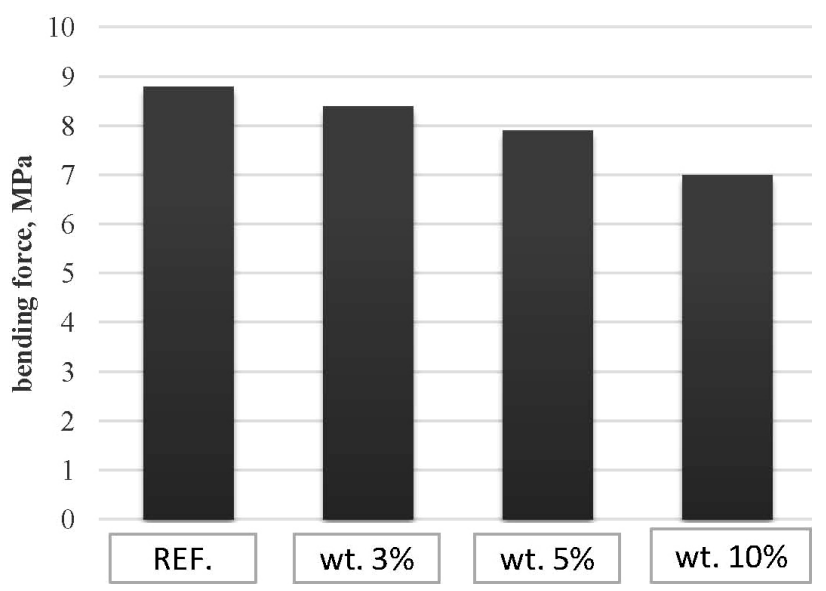

Figure 3: Average bending force distribution 


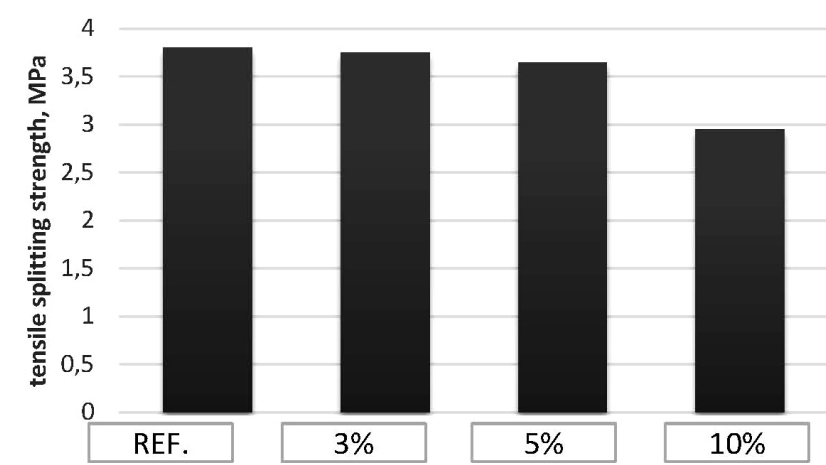

Figure 4: Average Brazilian tensile splitting (BTS) strength distribution

bending measurements. The addition of corncobs significantly affected the loss of strength.

Figure 5 shows the cross-section of the reference mix. Typical fragments of the concrete such as the aggregate and cement-matrix zones are visible. The addition of ground corncob can be seen in Figures 6-8 as white and yellow points comparable to small aggregates. They definitely stand out against the background of the dark matrix and thicker aggregate. There was no evidence that the additive caused more frequent crack formations, but it could have started them.

During the test, it was determined how the thermal parameters changed during the drying of the samples in open air and in a dryer at $40{ }^{\circ} \mathrm{C}$ over a period of $18 \mathrm{~h}$. The measurements were taken on two samples from each mixture, twice at the same sample site and the average values were calculated (Table 2).
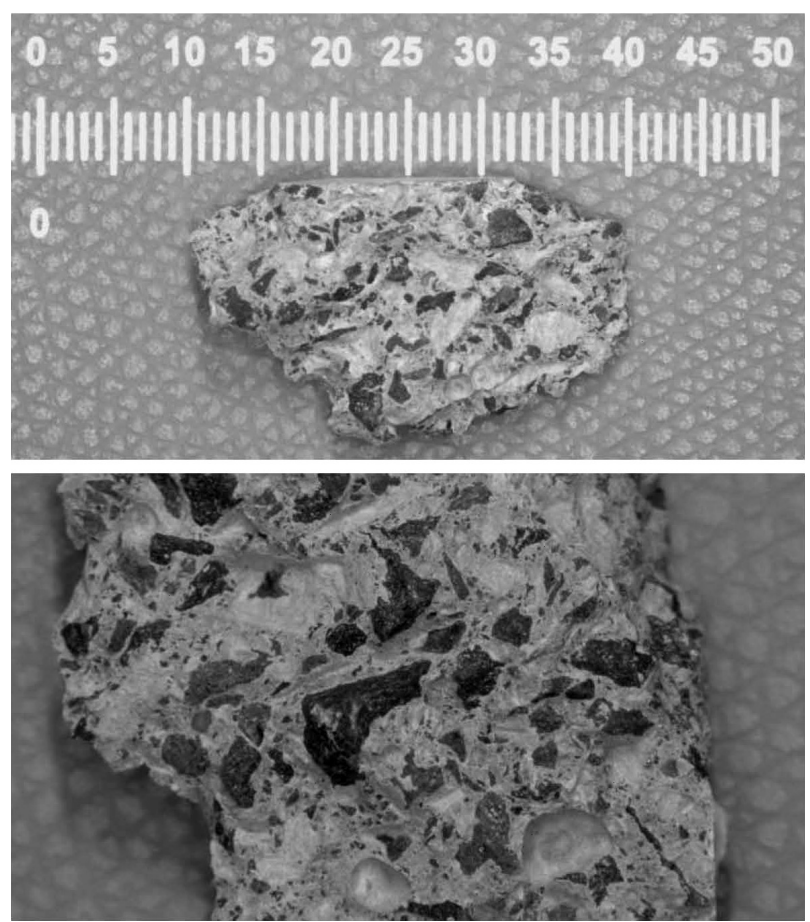

Figure 5: Cross-section of the reference mix
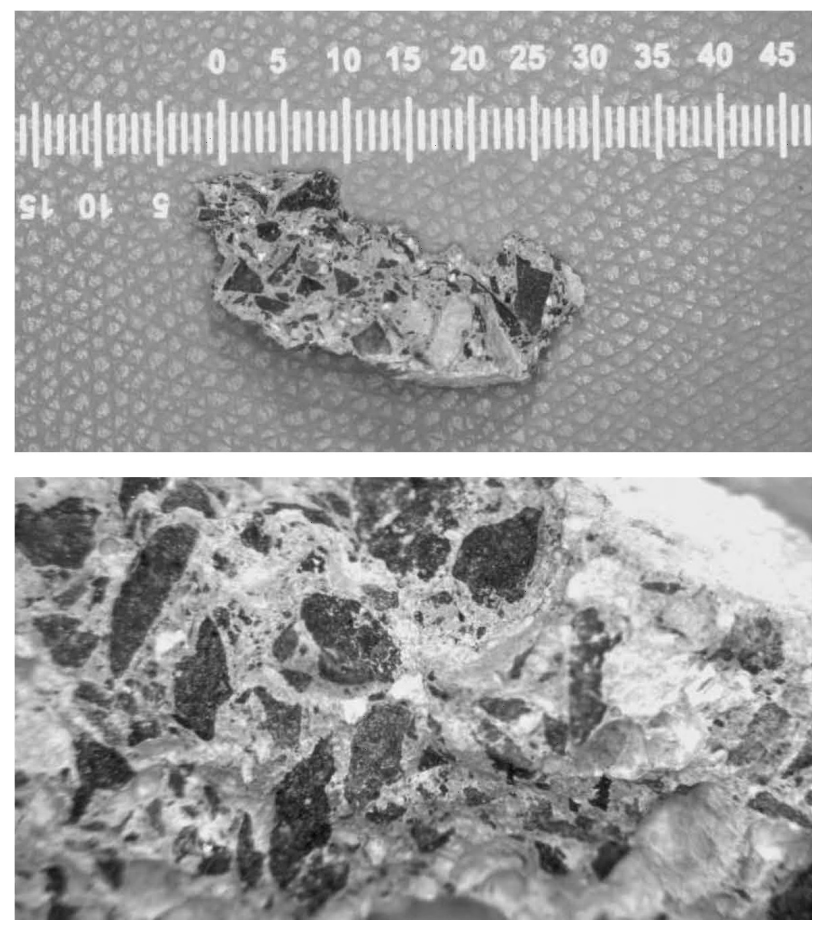

Figure 6: Cross-section of the mix with 3 w/\% ground corncob

At the beginning of the preparation of the concrete mix, the effect of adding corncobs for consistency was noted. As the amount of the organic additive increased, the mixture became drier (the slump cone test). This is probably due to the high-water demand of ground corncob.
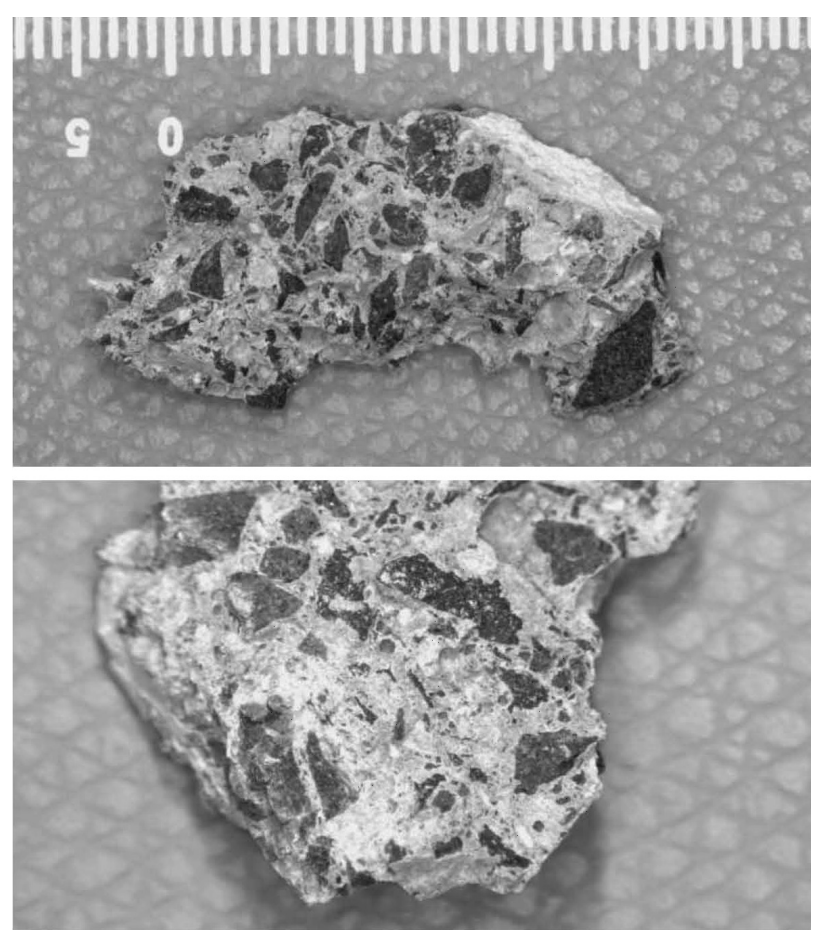

Figure 7: Cross-section of the mix with 5 w/\% ground corncob 

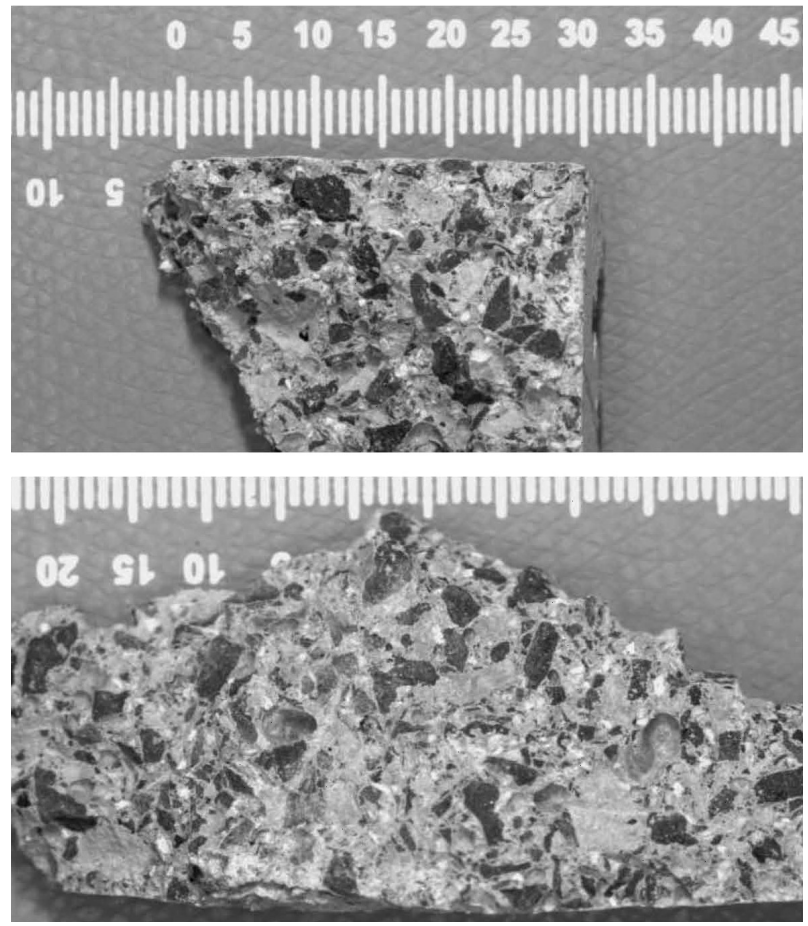

Figure 8: Cross-section of the mix with 10 w/\% ground corncob

When the test of the compressive strength of concrete was carried, a much higher stress value was obtained than previously designed. Unfortunately, with the growing amount of ground corncob, the compressive strength decreased. The corncob addition for testing the bending strength of concrete was the same. The results of the splitting tensile test were greater than the norm values, but the strength also decreased with the addition of ground corncob. The destruction of all the samples was considered to be correct.

The density of individual mixtures was calculated and the porosity of concrete was determined. The density of concrete decreased along with the increase in the amount of added ground corncob. The increasing porosity of concrete caused by the gradual addition of ground corncobs had a significant impact on this parameter.

The thermal tests of concrete showed that with a decreased density of concrete, the thermal conduction coefficient decreased. The addition of ground corncobs had a positive effect on the reduction of the thermal conductivity of concrete.

\section{CONCLUSIONS}

In conclusion, an addition of ground corncobs to concrete weakens the concrete in terms of strength. In contrast, it has a positive effect on the decrease in the thermal conductivity along with the increase in the amount of corncobs. This can have a positive effect on the insulation properties of concrete.

The changes in the bending strength and the high amount of cellulose from ground corncobs have a positive effect in the case of an addition to any kind of mortar.

\section{Acknowledgment}

The financial support from the Research Statutory Program financed by the Military University of Technology, Faculty of Civil Engineering and Geodesy, called "Research of materials and construction elements of military infrastructure special objects", No. 886/2019, is gratefully acknowledged.

\section{REFERENCES}

${ }^{1}$ K. Lyons, G. Swann, C. Levett, Produced but never eaten: a visual guide to food waste, The Guardian, Wed 12 Aug, 2015

${ }^{2}$ K. Bräutigam, J. Jörissen, C. Priefer, The extent of food waste generation across EU-27: different calculation methods and the reliability of their results, European Commission, JRC Technical Reports, 2017, doi:10.1177/0734242X14545374

${ }^{3}$ A. Abdullah, C. Lee, Effect of Treatments on Properties of CementFiber Bricks Utilizing Rice Husk, Corncob and Coconut Coir, Procedia Engineering, 180 (2017), 1266-1273: doi:10.1016/j.proeng. 2017.04.288

${ }^{4}$ R. Chmielewski, L. Kruszka, Cause and effect study of the structural failure of the historic complex of St. Anna's Church in Warsaw, MATEC Web of Conferences, 284 (2019), doi:10.1051/mateconf/ 201928405002

${ }^{5}$ R. Chmielewski, P. Muzolf, Selected problems of protection of historic buildings against the rainwater and the groundwater, MATEC Web of Conferences, 174 (2018), doi:10.1051/mateconf/ 2018174030012

${ }^{6}$ J. Pinto, B. Vieira, G. Pereira, C. Jacinto, P. Vilela, A. Paiva, S. Pereira, V. Cunha, H. Varum, Corn cob lightweight concrete for

Table 2: Thermal parameters of the samples

\begin{tabular}{|c|c|c|c|c|c|}
\hline & $\begin{array}{c}\text { Thermal conductivity } \\
\lambda /(\mathrm{W} / \mathrm{mK})\end{array}$ & $\begin{array}{l}\text { Thermal diffusivity } \\
\qquad a /\left(\mathrm{m}^{2} / \mathrm{s}\right)\end{array}$ & $\begin{array}{l}\text { Specific volumetric } \\
\text { heat } c_{v} /\left(\mathrm{J} / \mathrm{m}^{3} \mathrm{~K}\right)\end{array}$ & $\begin{array}{c}\text { Specific heat mass } \\
c_{\mathrm{p}} /(\mathrm{J} / \mathrm{kgK})\end{array}$ & $\begin{array}{c}\text { Density } \\
\rho_{0} /\left(\mathrm{kg} / \mathrm{dm}^{3}\right)\end{array}$ \\
\hline Ref. & $\begin{array}{l}1.548 \\
1.536 \\
\end{array}$ & $\begin{array}{l}9.82 \cdot 10^{-7} \\
8.76 \cdot 10^{-7}\end{array}$ & $\begin{array}{l}1.57 \cdot 10^{6} \\
1.75 \cdot 10^{6} \\
\end{array}$ & $\begin{array}{l}606 \\
678 \\
\end{array}$ & 2.59 \\
\hline $\operatorname{Mix} 1(3 w / \%)$ & $\begin{array}{l}1.442 \\
1.427 \\
\end{array}$ & $\begin{array}{l}8.99 \cdot 10^{-7} \\
9.57 \cdot 10^{-7}\end{array}$ & $\begin{array}{l}1.60 \cdot 10^{6} \\
1.49 \cdot 10^{6}\end{array}$ & $\begin{array}{l}635 \\
593 \\
\end{array}$ & 2.52 \\
\hline $\operatorname{Mix} 2(5 w / \%)$ & $\begin{array}{l}1.442 \\
1.442 \\
\end{array}$ & $\begin{array}{l}8.81 \cdot 10^{-7} \\
8.48 \cdot 10^{-7}\end{array}$ & $\begin{array}{l}1.64 \cdot 10^{6} \\
1.70 \cdot 10^{6} \\
\end{array}$ & $\begin{array}{l}654 \\
679 \\
\end{array}$ & 2.50 \\
\hline $\operatorname{Mix} 3(10 w / \%)$ & $\begin{array}{l}1.301 \\
1.177\end{array}$ & $\begin{array}{l}8.65 \cdot 10^{-7} \\
8.40 \cdot 10^{-7}\end{array}$ & $\begin{array}{l}1.50 \cdot 10^{6} \\
1.40 \cdot 10^{6}\end{array}$ & $\begin{array}{l}627 \\
584 \\
\end{array}$ & 2.40 \\
\hline
\end{tabular}


non-structural applications, Construction and Building Materials, 34 (2012), 346-351, doi:10.1016/j.conbuildmat.2012.02.043

${ }^{7}$ J. Faustino, E. Silva, J. Pinto, E. Soares, V. M. C. F. Cunha, S. Soares, Lightweight concrete masonry units based on processed granulate of corn cob as aggregate, Materiales de Construccion, 65 (2015), doi:10.3989/mc.2015.04514

${ }^{8}$ S. Thakur, S. Saraswat, D. Jain, Use of Ash of Agricultural Waste as Partial Replacement of Cement in Concrete (Rice Husk Ash, Saw Dust Ash, Wheat Straw Ash), International Journal of Engineering Research and Management (IJERM), 01 (2014), 169-172, doi:10.3390/ma12071112

${ }^{9}$ J. Prusty, S. Patro, S. Basarkar, Concrete using agro-waste as fine aggregate for sustainable built environment - a review, International Journal of Sustainable Built Environment, 5 (2016), 312-333, doi:10.1016/j.ijsbe.2016.06.003

${ }^{10}$ R. Chmielewski, A. Bak, Analysis of technical condition of footbridges over the railways in danger of collapse, MATEC Web of Conferences, 284 (2019), doi:10.1051/matecconf/201928401001

${ }^{11}$ H. Arel, E. Aydin, Use of Industrial and Agricultural Wastes in Construction Concrete, ACI Materials Journal, 115 (2018), doi:10.14359/ 51700991

${ }^{12}$ A. Dotun, O. Olalekan, A. Olugbenga, M. Emmanuel, Physical and Mechanical Properties Evaluation of Corncob and Sawdust Cement Bonded Ceiling Boards, International Journal of Engineering Research in Africa, (2019), 10.4028/www.scientific.net/JERA.42.65
${ }^{13}$ N. Belie, J. J. Lenehan, C. R. Braam, B. Svennerstedt, M. Richardson, B. Sonckf, Durability of Building Materials and Components in the Agricultural Environment, Part III: Concrete Structures, 76 (2000), 3-16, doi:10.1006/jaer.1999.0505

${ }^{14}$ R. Kosturek, M. Wachowski, L. Śnieżek, M. Gloc, The Influence of the Post-Weld Heat Treatment on the Microstructure of Inconel 625/Carbon Steel Bimetal Joint Obtained by Explosive Welding, Metals, 9 (2019), 246, doi:10.20944/preprints201812.0252

${ }^{15}$ A. Bak, R. Chmielewski, Analysis of repair works to remove the effect of structural failure after a gas explosion, MATEC Web of Conferences, 284 (2019), doi:10.1051/matecconf/201928402002

${ }^{16}$ C. Grădinaru, A. Şerbănoiu, D. Babor, G. Sârbu, When Agricultural Waste Transforms into an Environmentally Friendly Material: The Case of Green Concrete as Alternative to Natural Resources Depletion, Journal of Agricultural and Environmental Ethics, 32 (2019), 77-93, doi:10.1007/s10806-019-09768-1

${ }^{17}$ M. Wachowski, L. Sniezek, I. Szachogluchowicz, R. Kosturek, T. Plociński, Microstructure and fatigue life of $\mathrm{Cp}-\mathrm{Ti} / 316 \mathrm{~L}$ bimetallic joints obtained by means of explosive welding, Bulletin of the Polish Academy of Sciences, Technical Sciences, 66 (2018), 925-933, doi:10.24425/bpas.2018.125940

${ }^{18}$ A. Bak, R. Chmielewski, The influence of the fine fractions content in non-cohesive soils on their compactibility and the CBR value, Journal of Civil Engineering and Management, 25 (2019) 4, doi:10.3846/jcem.2019.9687 